\title{
METHODOLOGY AND DEVICE TO OBTAIN TORSIONAL SHEAR STRENGTH OF GLUED JOINTS
}

\author{
Alfredo Petrauski ${ }^{*}$, Sandra Maria Ferreira Couri Petrauski ${ }^{2}$, Ricardo Marius Della Lucia ${ }^{3}$, Mateus Couri \\ Petrauski $^{4}$ \begin{abstract}
alfredo.petrauski@unioeste.br
${ }^{2}$ Universidade Estadual do Oeste do Paraná - UNIOESTE, Centro de Ciências Exatas e Tecnológicas - CCET, Cascavel, Paraná, Brasil Sandra.petrauski@unioeste.br

${ }^{3}$ Professor aposentado da Universidade Federal de Viçosa - UFV, Departamento de Engenharia Florestal, Viçosa, Minas Gerais, Brasil ricardodella1946@gmail.com

${ }^{4}$ Universidade Estadual do Oeste do Paraná - UNIOESTE, Centro de Ciências Exatas e Tecnológicas - CCET, Cascavel, Paraná, Brasil mateus.petrauski@unioeste.br
\end{abstract} \\ ${ }^{1 *}$ Universidade Estadual do Oeste do Paraná - UNIOESTE, Centro de Ciências Exatas e Tecnológicas - CCET, Cascavel, Paraná, Brasil -
}

Received for publication: 28/05/2019 - Accepted for publication: 07/10/2019

\begin{abstract}
Resumo
Metodologia e aparato para obtenção da resistência de juntas coladas ao cisalhamento na torção. Este trabalho apresenta uma metodologia para obtenção da resistência ao cisalhamento de juntas coladas, por momento de torção. A normalização vigente obtém esta resistência por meio de ensaios de compressão. São também apresentados os aparatos idealizados. A motivação para conceber este ensaio está relacionada à possibilidade de execução de estruturas coladas em madeira, cujas ligações recebam simultaneamente momento fletor, força cortante e força normal. Admitiu-se a hipótese de que a resistência das juntas pode ser diferenciada dependendo do tipo de solicitação. A metodologia é relativamente simples e para obtenção dos resultados utiliza-se fórmulas da Resistência dos Materiais. Foram comparados os resultados de resistência de 198 corpos de prova, testados pela metodologia normatizada, com igual número de corpos de prova feitos e ensaiados com a metodologia sugerida, totalizando 396 ensaios. Deste total, 208 foram colados com resorcinol formaldeído e $188 \mathrm{com}$ adesivo à base de óleo de mamona. A madeira utilizada foi o Eucalyptus sp. Os corpos de prova foram confeccionados segundo sete séries envolvendo colagem com os seguintes ângulos entre as fibras: $0^{\circ}, 15^{\circ}, 30^{\circ}$, $45^{\circ}, 60^{\circ}, 75^{\circ}$ e $90^{\circ}$. Independentemente do tipo de adesivo, houve diferença significativa para as resistências apresentadas pelos dois métodos. Dos sete ângulos estudados percebeu-se diferença em seis deles, exceto para o ângulo de $30^{\circ}$. A resistência ao cisalhamento por compressão foi afetada pelo ângulo de colagem, com perdas crescentes no sentido do aumento do ângulo. Ao contrário, a resistência oferecida pelas juntas testadas à torção, não pareceu afetada pelo ângulo de colagem.
\end{abstract}

Palavras-chave: madeira; adesivo; caracterização; procedimento

\begin{abstract}
This paper presents a methodology to obtain the shear strength of glued joints, at the torsion moment. In the current standards this strength is measured by compression tests. The device designed for this purpose are also presented. The motivation for this test is related to the possibility of execution of glued wooden structures with joints under bending moment, shear force and normal force simultaneously. It was admitted the hypothesis that the joint strength can be different depending on the test type. The methodology is relatively simple and in order to obtain the results classic equations from Mechanics of Materials were used. The strength results of 198 test specimens, tested by standard methodology, were compared, with an equal number of specimens made and tested with the proposed methodology, resulting in 396 tests. 208 specimens were glued with resorcinolformaldehyde and 188 with castor oil-based adhesive. The wood used was Eucalyptus sp. The specimens were made according to seven series involving gluing with the following angles between the fibers: $0^{\circ}, 15^{\circ}, 30^{\circ}, 45^{\circ}$, $60^{\circ}, 75^{\circ}$ and $90^{\circ}$. Regardless of the adhesive type, there was a significant difference for the strengths presented by the two methods. From the seven angles studied, it was noticed a difference in six of them, except for the $30^{\circ}$ series. The compression shear strength was severely affected by the gluing angle, with increasing losses towards higher angles. On the contrary, the strength offered by the joints tested by torsion did not seem affected by the gluing angle.

Keywords: wood; adhesive; characterization; procedure.
\end{abstract}

\section{INTRODUCTION}

Some structures which are able to be executed in Glued Laminated Timber (Glulam) may contain joints which are simultaneously subject to the following loads: bending moment (M), shear force (V) and normal force (N). It is the case, for instance, of the plane frame loaded in the plane of the structure, as illustrated in figure 1. It is a tri-articulated frame which was laminated and glued with rigid joints to the knots B and D. Couri Petrauski et

FLORESTA, Curitiba, PR, v. 50, n. 4, p. 1921 - 1930, out/dez 2020.

Petrauski, A. et.al.

ISSN eletrônico 1982-4688

DOI: $10.5380 /$ rf.v50 i4. 67140 
al. (2016), designed, executed and tested, until fail, five units of these frames and concluded for their technical viability judging strength and rigidity parameters.

The suitable performance of the presented structure depends on the strength and rigidity of its joints. As illustrated in the details of the figure, in these joints, the laminated timber as well as the glued surfaces must resist the indicated forces simultaneously. Still in this case, the load which will be predominant during design will be the bending moment (M) since this type of structure works fundamentally to bending. Trussed frames, however, depending on the loads arrangement, may work with normal force predominance $(\mathrm{N})$.

One of Engineering responsibilities is the need to predict the structural behavior of materials, in their different arrangements, in order to accomplish safe and economic design. In the context of wood-to-wood glued joints, the Brazilian standard NBR 7190 (ABNT, 1997) stablishes that the glued surfaces strength tests be made by imposing on the glued joints a shear force by compression, that is, by imposing a normal force $(\mathrm{N})$. A similar methodology is adopted, for instance, by the ASTM D905 (ASTM, 1994). In both cases, therefore, the parameters obtainment for design is associated to the evaluation of glued joints strength sheared by compression. The American standard, however, adopts specimens with a smaller size which are easier to be produced from wood boards.

In this context, aiming the design of glued joints, the hypothesis that the strength of these joints under bending moment on the wooden bars could result differently from the strength of joints under normal force was admitted. In figure 1, it is also illustrated that when a glued joint is subject to a bending moment $\mathrm{M}$ on the glulam element, this moment $\mathrm{M}$ is, actually, for the surface glued in parallel to the load plane, a torsion moment T. Thus, the motivation of this work comprehends two aspects: proposing a method to investigate the strength of glued joints to torsional shear and gathering evidence that this strength, under torsion, may be different from the strength under normal compression force.
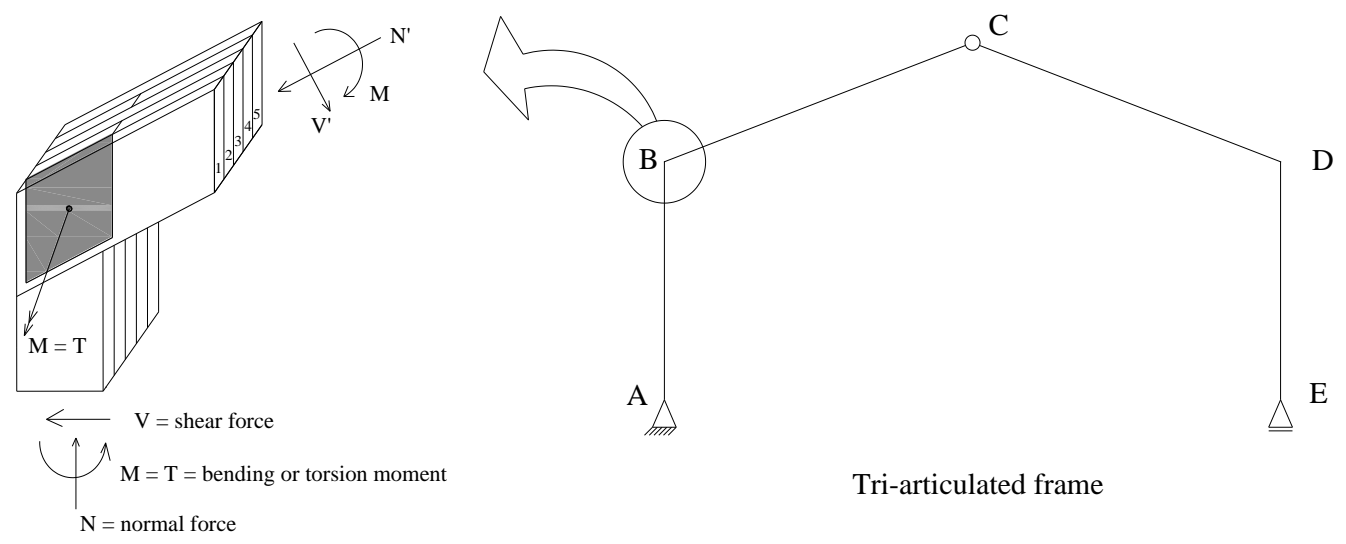

Figura 1. Pórtico triarticulado e detalhe do nó B, multilaminado e colado, com 5 lâminas e 4 planos colados. Figure 1. Tri-articulated frame and detail of knot B, glulam, with 5 laminated timbers and 4 glued surfaces.

Special mention must be made to the fact that, in knot B, the column laminated timbers (AB element) are glued to the beam laminated timbers (BC element) in an $\alpha$ angle which is not zero. This angle depends on the beam element slope adopted on the design. In this situation, there will be loads that will be tilted in relation to the fibers according to the same $\alpha$ angle. According to Kretschmann (2010), Hankinson's formula, as presented next, can be used to estimate the wood strength to oblique loads in relation to the direction of the fibers.

$$
\tau_{\alpha}=\frac{\tau_{a v g, 0^{\circ} \cdot \tau_{a v g, 90^{\circ}}}}{\tau_{a v g, 0^{\circ}} \cdot(\operatorname{sen} \propto)^{n}+\tau_{a v g, 0^{\circ}} \cdot(\cos \propto)^{n}}
$$

in which: $\tau_{\alpha}=$ shear stress estimated for a gluing $\alpha$ angle among the fibers $(\mathrm{MPa}), \tau_{\mathrm{avg}, 0^{\circ}}=$ average shear stress obtained for gluing at $0^{\circ}(\mathrm{MPa}), \tau_{\text {avg }, 90^{\circ}}=$ average shear stress obtained for gluing at $90^{\circ}(\mathrm{MPa}), n=$ formula exponent of sine and cosine.

According to Kretschmann (2010), the formula can be applied to strengths and other elastic properties, such as compression, tension and bending strengths, hardness and elasticity modulus. In his work, he suggests values of the $n$ exponents to be used in each case. In Brazil, the standard NBR 7190 (ABNT, 1997) adopts Hankinson's formula and suggests the $n$ exponent with the value equal to 2 for estimates of compression and tension strengths. 
The use of Hankinson's formula, however, is not unanimous among researchers. Logsdon et al. (2014) studied 4 equations to estimate wood strength to inclined tension, including Hankinson's formula. The results obtained, with Aspidosperma populifolium A. DC. specimens, show that the best adjustment for the formula was reached using $n$ exponents above 2 . Nonetheless, according to researches, the formula used with $n=2$ can be considered safe, once it underestimates the values obtained experimentally. Mascia et al. (2011) had already compared Hankinson's formula with Tsai-Wu criterium, developed for anisotropic materials. In this research, the experimental data were comprehended by Hankinson's curves used with the exponents $n=1,5$ and $n=2$. Logsdon et al. (2014) and Mascia et al. (2011) acknowledged difficulties in the use of Tsai-Wu model given the high number of parameters to be obtained.

In the present paper, Hankinson's formula was used with the sine and cosine exponent ( $n$ ) equal to 2 . The use of this formula in this research was done exclusively to illustrate the strength variation behavior of joints glued to different angles when failed under compression force. Some researchers in Brazil, in the decades of 1980 and 1990, obtained evidence of this application possibility.

\section{MATERIAL and METHODS}

\section{Methodology and device}

In order to make the test feasible, it was sought a viable solution in the four-point bending test of a beam, which has a part of the element under a pure bending condition. This is illustrated in figure 2. In this figure, to the left, it is illustrated the metallic device in perspective. It was made using 20 milimeter thick steel plates forming a framework. The device consists of two identical parts which are joined at one end by the specimen (central part of the test). Each part fixates a side of the specimen. For this, there are screws with $8 \mathrm{~mm}$ diameter which allow the fixation of specimens in the test position, through moving bars tightened by the screws. In the figure, to the right, it is presented a frontal view of the test scheme. In this case, in the center, it is illustrated a specimen with a hatch. In the BC stretch, the beam formed by the two parts of the device, linked by the specimen, will be subject to a bending moment $\mathrm{M}$. The value of this moment is equal to $P a$, being $P$ the value of each concentrated load applied to the beam and $a$ the distance between each support and the load position. In the tests it was adopted the distance $a$ as equal to $24 \mathrm{~cm}$. This resulted in a total span between supports of $72 \mathrm{~cm}$.
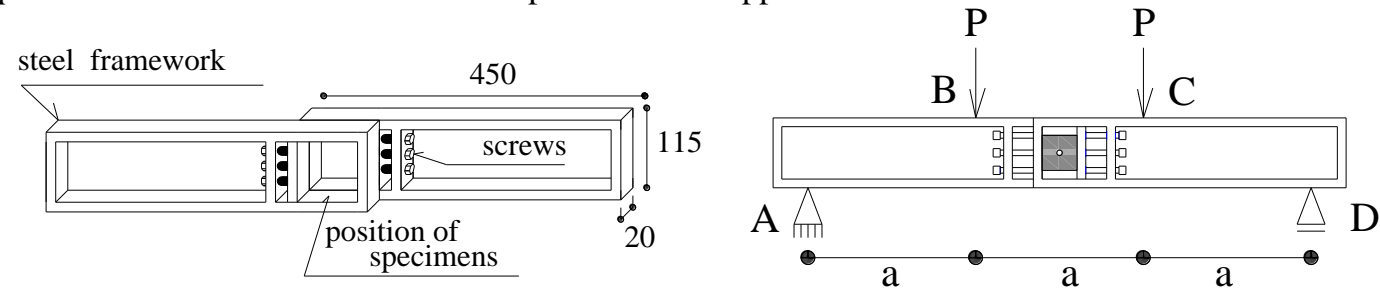

Figura 2. Aparato para cisalhamento à torção e esquema de carga durante o teste, dimensões em milímetros. Figure 2. Device for torsional shear and load scheme during the test, dimensions in millimeters.

The specimen idealized for this test is illustrated in figure 3(a). It was adopted with dimensions similar to those proposed by ASTM D905 (1994). This was made to facilitate the execution and, also, the comparison of results. The tests were applied with the dimension $b$ equal to $20 \mathrm{~mm}$ and the dimension $h$ in the interval that comprehends: $50 \leq h \leq 55 \mathrm{~mm}$. It is interesting to stand out, however, that the device allows $h$ of about $75 \mathrm{~mm}$. This possibility was admitted to accomplish other comparative tests. In figure 3(a), it is highlighted an internal circular area which comprehends the glued area resistant to torsion. In 3(b), it is illustrated the idea of the bending moment $\mathrm{M}$ transference, applied the device, to the glued area of the specimen so that it turns into a torsion moment T. It was admitted a linear distribution of normal stresses $(\sigma)$, acting in opposite portions of the specimen so that two binaries act loading the glued area. In figure 3(c), it is presented, in a frontal view, the transference of normal stresses $\sigma$, acting in opposite sides of the specimen, so that the torsion moment is generated equally to the bending moment $\mathrm{M}$ which acts on the device. Finally, in 3(d), also in a frontal view, it is presented the expected distribution of the shear stresses $\tau$, acting on the glued circular surface. It is noticed that the stress $\tau$ on the border is the maximum in the glued surface.

In this figure, the indicated variables represent:

$\mathrm{T}=\mathrm{M}=$ torsion moment and bending moment (N.m);

$\sigma_{\text {máx }}=$ maximum normal stress associated to the bending moment $\mathrm{M}\left(\mathrm{N} \cdot \mathrm{m}^{-2}\right)$;

$\sigma=$ internal normal stress acting at a y height of the neutral line $\left(\mathrm{N} . \mathrm{m}^{-2}\right)$;

$\tau_{\text {máx }}=$ maximum shear stress associated to the torsion moment $\mathrm{T}\left(\mathrm{N} \cdot \mathrm{m}^{-2}\right)$;

$\mathrm{b}=$ thickness of a glued laminated timber for specimen composition (m);

FLORESTA, Curitiba, PR, v. 50, n. 4, p. 1921 - 1930, out/dez 2020.

Petrauski, A. et.al.

ISSN eletrônico 1982-4688

DOI: $10.5380 /$ rf.v50 i4. 67140 
$\mathrm{h}=$ specimen height $(\mathrm{m})$;

$\mathrm{r}=$ external ray of the glued area $(\mathrm{m})$;

$\mathrm{R}=$ resulting force of the normal stresses $(\mathrm{N})$;

$\mathrm{c}=$ specimen geometric center; and

L.N = Neutral Line.

Some verifications were made in order to guarantee that there would not be failure of the wood, for instance, by compression crushing, caused by the normal stresses $\sigma$. Such verifications allowed the conclusion that the specimen would fail due to shear.

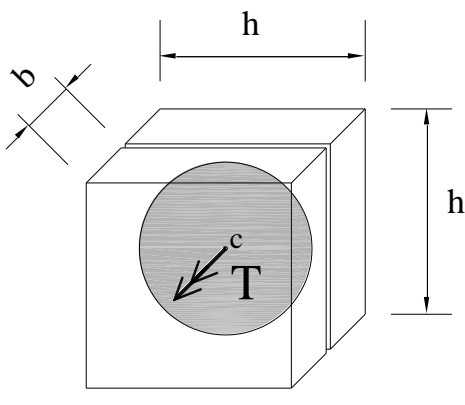

( a )

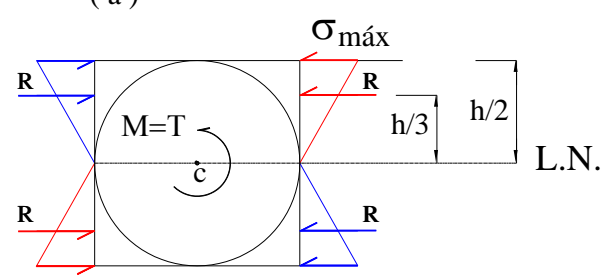

(c)

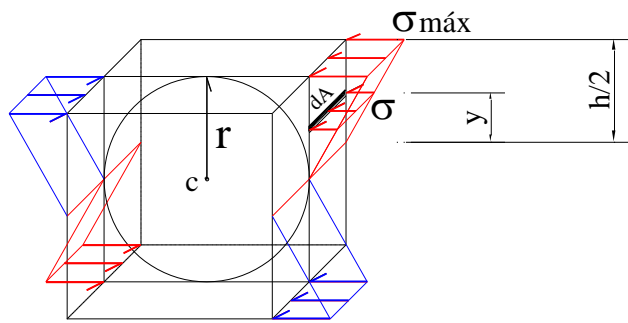

( b )

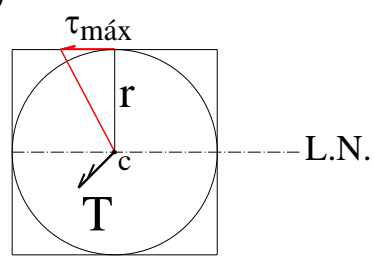

( d )

Figura 3. Esquema da ação das tensões normais e de cisalhamento no corpo.

Figure 3. Scheme of the normal and shear stresses action on the specimen.

However, the interest in performing the test is to quantify the glued surface shear strength ( $\left.\tau_{\max }\right)$ to the torsion force. It is known due to the Mechanics of the Materials that in this situation the shear stresses distribution is the one indicated in figure 3(d), with the maximum stress acting on the circular area border and, with linear decrease, becoming null in the center. In this case, the equation which was used can be seen, for instance, in Hibbeler (2010), and is presented as:

$$
\tau_{\text {máx }}=\frac{T \cdot r}{I_{p}}=\frac{M \cdot r}{I_{p}}=\frac{P \cdot a \cdot r}{I_{p}}
$$

in which: $P$ is the force applied on the device, according to the scheme in figure $2(\mathrm{~N}), a$ is the distance between a support and the $P$ load position, according to figure $2(\mathrm{~m}), r$ is the glued area external ray and $\mathrm{I}_{\mathrm{P}}$ is the polar moment of inertia of the glued circular surface $\left(\mathrm{m}^{4}\right)$.

This equation allows the calculation of the maximum shear stress suffered by the glued area. Nonetheless, the polar moment of inertia calculation must consider a hollow circular surface. The obtainment of the shear resistant circular area was thought to be executed by using a second device. This is illustrated in the following figure 4. For this, the specimen already glued receives a hole in its central position. It is then attached to an axis which is perpendicular to a circular saw blade, as illustrated in figure 4(a). It is adjusted to a cutting height and the specimen is forced against the saw, rotating the axis in which it is attached, in order to set up the desired circular area. In figure 4(b), to the left, it is presented a specimen being tested in the idealized device, in a Universal Testing Machine (UTM).

Having done this operation, the glued surface gets circular with a hole in its center. In the conducted tests the holes were made with $8 \mathrm{~mm}$ diameter drills. This way, in the calculation of the polar moment of inertia, it is used the equation presented below. It is observed that this glued section loss does not generate a significative performance loss of the specimen. In fact, such loss in the polar moment of inertia is inferior to $0,07 \%$ if adopting $\mathrm{r}=25 \mathrm{~mm}$. Therefore, the necessary execution of this hole does not affect the aim of this test. Besides that, the correction in the $\mathrm{I}_{\mathrm{p}}$ eliminates this problem. 


$$
I_{p}=\frac{\pi}{2}\left(r^{4}-r_{\text {hole }}^{4}\right)
$$

in which: $\mathrm{r}_{\text {hole }}$ is the ray of the hole $(\mathrm{m})$ and $\mathrm{r}$ is the circular area external ray (m).

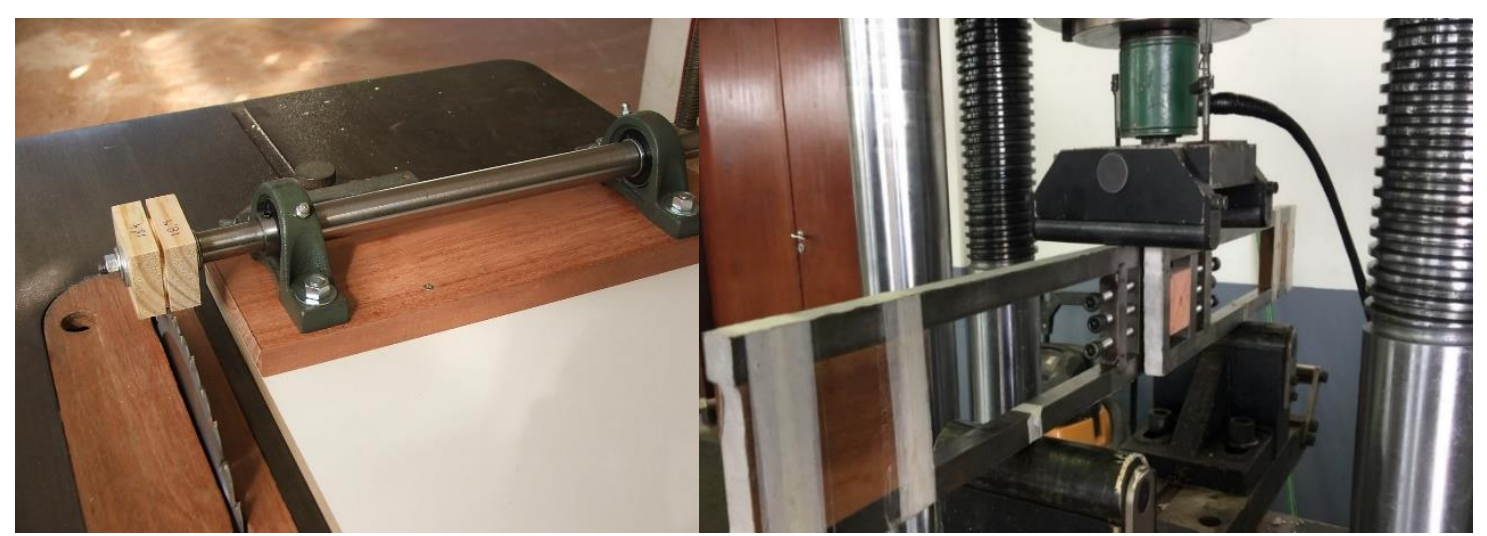

(a)

(b)

Figura 4 - 4(a)-Preparação da área circular no corpo de prova, e 4(b)- Ensaio no aparato, em MUE.

Figure 4 - 4 (a) - Preparation of the circular area in the specimen, and 4 (b) - Torsional test in the device, using the Universal Testing Machine.

\section{Conducted tests}

The test reported next comprehended an experiment conducted to evaluate the device and the hypothesis that the glued surfaces shear strength can be different when the test is conducted by normal compression force or torsion moment.

It was used Eucalyptus sp. wood boards, commercially called Lyptus, for the selection and preparation of laminated timber for the programmed tests. There was an interest in confronting the shear strength results, obtained by two methodologies: the one stablished by ASTM D-905 (1994) and the one proposed here. In the first one, the shearing happens by imposing compression normal force. In the second one, by imposing torsion moment with the use of the idealized device.

The test was planned to obtain results for two adhesives: resorcinol-formaldehyde and bicomponent castor oil-based adhesive. It was produced glued joints which, additionally, generated specimens glued at different angles between the wood fibers, for both adhesives. The following bonding angles were adopted: $0^{\circ}, 15^{\circ}, 30^{\circ}, 45^{\circ}, 60^{\circ}$, $75^{\circ}$ and $90^{\circ}$. The production of joints glued at different angles between the fibers required an adaptation of what was predicted in the standard. It was necessary to work with larger laminated timbers, in order to rotate one in relation to the other, obtaining the desired angles.

It was performed a special care with the selection of available wood density. Lyptus is not commercialized from a single species. As a consequence, there can be a considerable variation in apparent density in a same lot. Thus, each laminated timber produced in the initial moment had its mass and dimensions determined, in order to obtain an estimate of their densities. After that, with this data, the laminated timbers were chosen for the different experimental treatments, so that there would not be differentiated densities by treatment.

A total of 188 specimens made with castor oil-based adhesive and 208 made with resorcinolformaldehyde were extracted and tested. Of these totals, half were produced and tested with the ASTM D 905 (1994) methodology and half with the proposed methodology. Still about the number of specimens by gluing angle, it was stablished a minimum of 12 specimens by angle, seeking to produce an increased amount of specimens for the $0^{\circ}$ and $90^{\circ}$ angles, since their results consist in input data to Hankinson's formula. The formula was used with $n=2$ and the average values of the shear strength parallel and perpendicular to the fibers, obtained in the standardized tests, were used in the equation.

The joints were glued in an environment which indicated, in average, a temperature of about $23,5^{\circ} \mathrm{C}$ and relative air humidity of about $65 \%$. It was adopted, for both adhesives, a gluing pressure of 1,3 MPa, null open production time and closed production time of 25 minutes. For the castor oil-based adhesive, it was adopted a polyol isocyanate mass proportion of 1:1,32. For the resorcinol, properly mixed according to the manufacturer's recommendation, it was used consumption of $250 \mathrm{~g} / \mathrm{m}^{2}$ and for the castor oil-based adhesive, $300 \mathrm{~g} / \mathrm{m}^{2}$.

FLORESTA, Curitiba, PR, v. 50, n. 4, p. 1921 - 1930, out/dez 2020. 
After glued, the joints stayed under pressure for not less than 10 hours. When extracted, the specimens were put in a climatic chamber with $50 \%$ of relative humidity and $23^{\circ} \mathrm{C}$ of temperature.

The standardized specimens were tested in an Universal Testing Machine, with the specific standard device, following what is described in ASTM D905 (1994). The specimens made according to the new methodology, were also tested in the same machine, with the device illustrated in figure 4(b) and the machine cylinder head advance speed similar to the one adopted in the standardized methodology, that is, $5 \mathrm{~mm}$ per minute. In the experiment, the specimens of the proposed methodology were executed with $\mathrm{b}=20 \mathrm{~mm}, \mathrm{~h}=55 \mathrm{~mm}$ and glued area rays of $25 \mathrm{~mm}$.

After the tests, there was a determination of all specimens humidity. For this, the portion of the specimen with hiher wood loss was used to determine the apparent density. The other portion was destinated to humidity determination. In the determination of the apparent density, the volume was obtained by immersing the specimens in metallic mercury.

It is convenient to highlight that the statistical evaluation of the density distributions and obtained strength has been done, by adhesive and gluing angle. By analysing the results, it was confirmed their normality and, also, homoscedasticity. It was proceeded, then, to the analysis of variance.

\section{RESULTS}

The medium humidity obtained after the failure of the specimens was $11,16 \% \mathrm{DMB}$, with standard deviation of $0,79 \%$. The apparent densities were, in average, about $0,8 \mathrm{~g} / \mathrm{cm}^{3}$. However, the presented results have the strength corrected to the standard moisture content of $12 \%$, according to the NBR 7190 (ABNT, 1997).

The absence of density differences by test and gluing angles was verified, which was desired. As it is known, density is a factor which can have influence over the mechanical performance of the wood. Therefore, in this expiriment, the accomplished previous selection succeeded.

In figure 5(a), it is presented the results obtained for the strength of the glued joints with resorcinolformaldehyde adhesive, by test type and gluing angles. In figure 5(b) are the results for the castor oil-based adhesive. The results presented in black correspond to those conducted by compression and the ones presented in red are the ones obtained by torsion. Of what is illustrated, it is noticed that, as the gluing angle is increased, in the standardized test, there is a sensible shear strength loss. This decrease was similar to the one estimated by Hankinson's formula. In these figures, the strength estimates obtained by Hankinson's formula were made by using the averages obtained for $0^{\circ}$ and $90^{\circ}$ strength and are presented in blue.

Although, in this work, it was not desired to evaluate Hankinson's formula, what is sought to illustrate in figure 5 is that the strength loss of the specimens tested according to the standardized methodology had similar behavior to the estimates given by the model.

In the torsion tests, it does not seem to have significant strength loss with the increase of the gluing angles. According to what is illustrated in figure 5, regardless of the angle, the strength in this test tended to an average close to 10,7 MPa for resorcinol-formaldehyde and 9,5 MPa for the castor oil-based adhesive.

Table 1 summarizes the ANOVA, by adhesive, for the dependent variable strength due to the test type, gluing angles and possible interaction.

As presented, there was a significant effect of both factors: test and angle and, also, the interaction between the factors was significant. This happened for the specimens glued with both adhesive types. The biggest interest for the research, however, was to identify possible differences in the strengths presented by both test types. Thus, after the average tests, it was obtained what is indicated in table 2.

In table 2, it is noticed, for both adhesives, the same tendency observed in figure 5 which illustrated the results, that is: in the compression test, regardless of the adhesive, there is accentuated strength loss as the gluing angle between the fibers is increased. In the torsion conducted tests, for both adhesives, the observed strengths kept practically unchanged. For the resorcinol-formaldehyde adhesive, for instance, there was no significant difference in the strength among the seven series of angles. Therefore, the strengths manifested under torsion present themselves with little variation when changing the gluing angle.

FLORESTA, Curitiba, PR, v. 50, n. 4, p. 1921 - 1930, out/dez 2020.

Petrauski, A. et.al.

ISSN eletrônico 1982-4688 


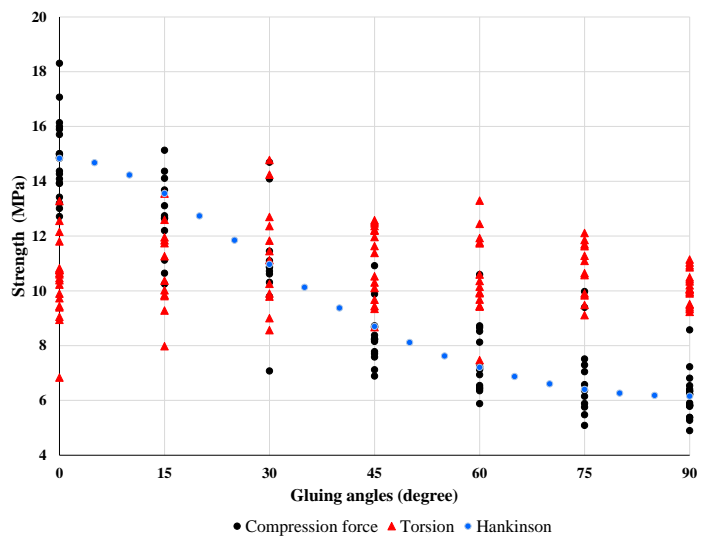

(a)

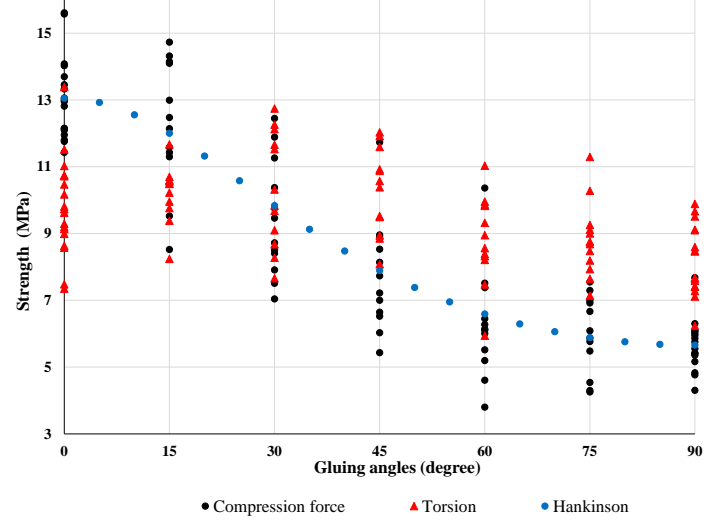

( b )

Figura 5. Comportamento geral das resistências observadas para corpos de prova colados com adesivo resorcinol formaldeído 5(a) e adesivo à base de óleo de mamona 5(b), por tipo de ensaio e ângulos estudados.

Figure 5. General behavior of the observed strengths for the specimens glued with resorcinol-formaldehyde 5(a) and castor oil-based adhesive (b), by type of test and studied angles.

Tabela 1. Resumo da ANOVA para a resistência de juntas coladas, por adesivo.

Table 1. Summary of the ANOVA for the glued joints strength, by adhesive.

\begin{tabular}{cccc}
\hline & \multicolumn{4}{c}{ Bicomponent castor oil-based adhesive } & F Ratio \\
\hline Variation source & df & Mean square & $17,74^{* *}$ \\
Test & 1 & 33,6037 & $52,41^{* *}$ \\
Angle & 6 & 99,285 & $24,92^{* *}$ \\
Test x Angle & 6 & 47,20 & \\
Residue & 174 & 1,894 & F Ratio \\
\hline \multicolumn{4}{c}{ Resorcinol-formaldehyde adhesive } \\
\hline Variation source & df & Mean square & $32,86^{* *}$ \\
Test & 1 & 60,476 & $51,07^{* *}$ \\
Angle & 6 & 93,983 & $47,96^{* *}$ \\
\hline
\end{tabular}

** upon $1 \%$ of probability.

When the results of compression $\times$ torsion are compared, for each adhesive, it is noticed that, of the seven series, in 6 of them, there was significant difference between the tests. Coincidence or not, regardless of the adhesive, it was for the same $30^{\circ}$ angle that the strength results could be considered equal. Regardless of the test or adhesive, the lower average strengths were obtained for the glued joints at $90^{\circ}$.

Tabela 2. Resumo do teste de médias para a interação significativa teste em função do ângulo de colagem para os adesivos à base de óleo de mamona e resorcinol formaldeído.

Table 2. Summary of the average test for the significant interaction test in function of the gluing angle for the castor oil-based and resorcinol-formaldehyde adhesives.

\begin{tabular}{ccccccc}
\hline $\begin{array}{c}\text { Angle } \\
\text { (degrees) }\end{array}$ & \multicolumn{2}{c}{$\begin{array}{c}\text { Average strength }(\mathrm{MPa}) \text { for the castor oil-based } \\
\text { adhesive }\end{array}$} & \multicolumn{3}{c}{$\begin{array}{c}\text { Average strength (MPa) for the resorcinol- } \\
\text { formaldehyde adhesive }\end{array}$} \\
\cline { 2 - 7 } & $\begin{array}{c}\text { Number of } \\
\text { specimens }\end{array}$ & Compression & Torsion & $\begin{array}{c}\text { Number of } \\
\text { specimens }\end{array}$ & Compression & Torsion $^{1}$ \\
\hline 0 & 18 & $13.05(10.74)^{\mathrm{a}}$ & $9.77(14.47)^{\mathrm{b}}$ & 20 & $14.84(9.45)^{\mathrm{a}}$ & $10.43(13.56)^{\mathrm{b}}$ \\
15 & 12 & $12.27(12.24)^{\mathrm{a}}$ & $10.22(15.38)^{\mathrm{b}}$ & 12 & $12.72(11.81)^{\mathrm{a}}$ & $10.85(14.48)^{\mathrm{b}}$ \\
30 & 12 & $9.44(20.44)^{\mathrm{a}}$ & $10.32(18.99)^{\mathrm{a}}$ & 12 & $11.05(17.47)^{\mathrm{a}}$ & $11.33(17.30)^{\mathrm{a}}$ \\
45 & 12 & $7.74(12.67)^{\mathrm{b}}$ & $10.27(13.05)^{\mathrm{a}}$ & 16 & $8.37(11.74)^{\mathrm{b}}$ & $11.09(12.08)^{\mathrm{a}}$ \\
60 & 12 & $6.28(20.51)^{\mathrm{b}}$ & $8.82(17.11)^{\mathrm{a}}$ & 14 & $7.48(17.21)^{\mathrm{b}}$ & $10.58(14.26)^{\mathrm{a}}$ \\
75 & 12 & $5.98(25.14)^{\mathrm{b}}$ & $8.81(11.37)^{\mathrm{a}}$ & 12 & $6.88(21.87)^{\mathrm{b}}$ & $10.77(9.30)^{\mathrm{a}}$ \\
90 & 16 & $5.66(14.74)^{\mathrm{b}}$ & $8.20(7.34)^{\mathrm{a}}$ & 18 & $6.15(13.56)^{\mathrm{b}}$ & $10.13(5.94)^{\mathrm{a}}$ \\
\hline
\end{tabular}

${ }^{1}$ averages, on the line, by adhesive, followed by the same letter, do not differ at $5 \%$ level by Tukey's test. Between parenthesis is the coefficient of variation (C.V.\%)

FLORESTA, Curitiba, PR, v. 50, n. 4, p. 1921 - 1930, out/dez 2020.

Petrauski, A. et.al.

ISSN eletrônico 1982-4688 
In addition to table 2 , it is presented between parenthesis, the obtained coefficients of variation. The magnitude observed for the coefficients of variation is as expected for wood characterization results. The lower coefficients of variation in the torsion test were found for $90^{\circ}$ glued joints. On the contrary, in the standardized test, the lower coefficients of variation were associated to $0^{\circ}$ glued joints.

In figure 6 , it is presented the aspects of the specimens fail according to the proposed methodology. In this case, they were specimens glued with resorcinol-formaldehyde. The specimens presented in the superior part of the figure comprehend the ones glued at $45^{\circ}$ and the ones in the inferior part had parallel glued fibers. It is noticed that the general aspects of the fail surfaces are very similar to the ones of the standardized test specimens. Besides, in the illustrated cases, there was a high percentage of wood failure, above $70 \%$. Finally, it is interesting to highlight that the fail in the proposed methodology test is also of a fragile aspect. When the limit strength is reached under torsion, the device "disarms" causing that both its parts, previously united by the specimen, rotate around the center of the specimen and the parts loosen. The failure, therefore, most times, is fragile such as in the standardized test.

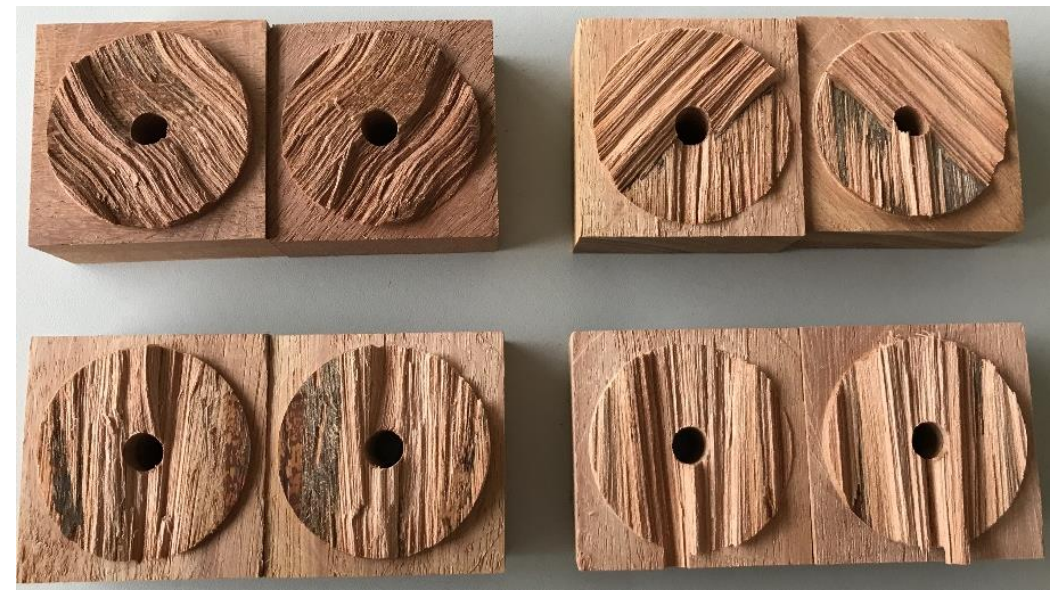

Figura 6. Corpos de prova rompidos à torção, colados à $45^{\circ}$ acima, e colados paralelos às fibras abaixo.

Figure 6. Torsion failed specimens, glued at $45^{\circ}$, in the superior part of the picture, and parallel to the fibers, in the inferior part.

\section{DISCUSSION}

The main contribution of this research was the evidence that the glued joints strength, to shear, can differ depending on the type of load which promotes the failure stress. In this work, the obtained results indicated that the strengths were kept practically unchanged with the variation of the gluing angle, when there was a torsion test, regardless of the adhesive. Besides that, the strength results, by gluing angle, regardless of the adhesive, were different between both methods. The fact that they were statistically equal for the $30^{\circ}$ angle seems to be more related to the strength behavior in the standardized test. This strength falls with the increase of the angle and, therefore, for an angle, in this case, of $30^{\circ}$, it would equate to the strength presented in the method proposed here.

It is important to say that this new methodology can be interesting in the analysis and design of joints similar to the one illustrated in figure 1. It is the case of structures built and tested by Couri Petrauski et al. (2016), for instance. In these structures, due to the geometry, the gluing angle between the laminated timbers of the columns and the beam ones is close to $70^{\circ}$, depending on the beam slope. If the standardized test strength parameters are used there is a tendency to the joints being oversized. This can happen since the results of the standardized test, for this case, underestimate the strength, considering that the predominant force is the bending moment. As a consequence, the application of this method can generate more economic design. The methodology proposed here would also be useful in designing beam joints executed by Lobão et al. (2012) in which it was used Eucalyptus sp. In this research, the authors attested a good structural performance of joints made in the center of beams with up to 4 meters of free span when the joints were made by additional laterally glued wood boards using resorcinol-formaldehyde.

Consequently, the application of the proposed methodology can be useful and generate more economic design when the predominant load on the joint to be executed is the bending moment and such load acts according to an axis perpendicular to the glued surfaces. In this situation, the bending moment acting on the glulam elements will be manifested as a torsion moment on the glued surfaces.

Lobão et al. (2012), when testing joints glued at $0^{\circ}$ and $90^{\circ}$ between the fibers and using the NBR 7190 (1997) methodology, found, equally, inferior strengths for the joints glued perpendicularly to the fibers. In this

FLORESTA, Curitiba, PR, v. 50, n. 4, p. 1921 - 1930, out/dez 2020.

Petrauski, A. et.al.

ISSN eletrônico 1982-4688

DOI: $10.5380 /$ rf.v50 i4. 67140 
work, considering the ASTM D 905 (1994) test, the joints glued at $90^{\circ}$ between the fibers presented the worst performance to shearing and, additionally, considering the series of 7 tested angles, there was a very good conformity with the estimates allowed by Hankinson's formula. In this context, for instance, in works published in the decades of 1980 and 1990 at the Brazilian Meeting on Timber and Timber Structures (EBRAMEM) editions, several researchers attested the validity of this formula as an estimator of glued joints shear strength tested by compression. To Logsdon et al. (2010), Hankinson's formula is a good estimator of the shear strength to forces inclined in relation to the direction of the fibers. However, the researchers recommend caution with the adequation of the expression sine and cosine exponents. In the present research, Hankinson's formula was not under analysis and, therefore, it was adopted the exponent 2, which is normally used. Even so, there was a very good adequation between the estimates and the values observed in the standardized tests by compression, according to what is illustrated in figure 5 .

For the extreme angles, $0^{\circ}$ and $90^{\circ}$, the compression test strengths are, respectively, maximum and minimum. This can mean that, in the design of a glued joint which is transmitting normal force (tension or compression), usual situation in trusses and the like, the situation which will require a bigger glued area happens, precisely, to glued joints involving higher angles. Besides that, in joints which work for bending moment, it seems, considering the evidence obtained here by using Lyptus, exaggerated to adopt strength parameters from the standard test. In this case, strength parameters obtained in the proposed test can generate the necessary safety, keeping the desired economy.

Another interesting fact is the nature of the stresses involved in both tests: in the standard test by compression, there is an invariable direction of the shear stress in relation to the glued fibers. It is the direction of the compression force which commands the action. On the contrary, in the proposed test, according to what is presented by Hibbeler (2010), for instance, the stress directions are continuously variable and perpendicular to the infinite rays of the circular area. Thus, the fact that these stresses, generated by the torsion moment, act in all directions, seems to minimize the gluing angle effect, turning the final strengths practically invariable.

Concerning the idealized, built and used devices, they seem to have properly accomplished the proposed aim. The main device can be executed with a lighter material and it is the case, for instance, of recommending structural aluminum as a more appropriate solution. In this research, considering the weight of the steel, it was added to the bending/torsion moment a portion associated to the weight of the equipment. The auxiliary device, responsible for giving the circular shape to the glued area, allows the task execution in a fast way, after some initial experience. A medium time, inferior to 2 minutes, allows the execution of a specimen. Furthermore, it seems that the circular area has advantages concerning another solution. The shear stress distribution in circular areas is very well characterized by the main authors of the Strength of the Materials and, consequently, the necessary calculations are sufficiently simple and known.

About the failures, they are fragile as observed in the standardized tests, that is, when lacking strength capacity, the specimen fails in a practically instant way and, in this case, the device "disarms". The fail surface shows, like in the standardized tests, the percentage of wood failure. This was presented in figure 6 and it is possible, with some adaptation, the estimate of the failure percentage.

Finally, considering it is a new methodological proposal, in essence, the proposition of a new glued joints characterization test, research results about the topic are still nonexistent. It may be, moreover, that the fact that the standards do not predict wood gluing with inclined fibers, also collaborates with the inhibition of such researches. Nonetheless, there are many situations in which such methodology can be applied in favor of more economic solutions and, probably, equally safe.

\section{CONCLUSIONS}

In the conditions of planning and development of this work, it can be concluded that:

- The glued joints strength to shear were significantly different when the tests were conducted with failures by compression and torsion.

- The proposed methodology was viable thanks to the idealized device, and the generated results presented coefficients of variation compatible to those who are particular of the wood technology and its characterization.

- For the standard tests, conducting the fail by compression, there is a sensible strength loss with the increasing of the gluing angle. This loss seems to be similar to what is estimated by Hankinson's formula.

- For the proposed test, there was not, considering the obtained results, significant loss of shear strength under torsion with the increase of the gluing angle.

- The design of glued joints with Eucalyptus sp. wood can be conducted with more economy, in the presence of bending moments, when the strength is estimated by the proposed procedure.

FLORESTA, Curitiba, PR, v. 50, n. 4, p. 1921 - 1930, out/dez 2020.

Petrauski, A. et.al.

ISSN eletrônico 1982-4688

DOI: $10.5380 /$ rf.v50 i4. 67140 


\section{REFERENCES}

AMERICAN SOCIETY FOR TESTING AND MATERIALS. Annual book of ASTM. Philadelphia, 1994. (Standards, 15.06, Adhesives)

ASSOCIAÇÃO BRASILEIRA DE NORMAS TÉCNICAS. NBR 7190: projeto de estruturas de madeira. Rio de Janeiro, 1997.

COURI PETRAUSKI, S.M.F.; SILVA, J.C.; PETRAUSKI, A.; DELLA LUCIA, R.M. Analysis of eucalyptus glued-laminated timber pórticos strutuctural performance. Revista Árvore, Viçosa, v.40, n.5, p. 931 - 939, 2016.

HIBBELER, R.C. Resistência dos Materiais. São Paulo: Pearson, 7 ed. 2010, 639 p.

KRETSCHMANN, D.E. Mechanical Properties of wood. In: Wood Handbook. Forest Products Laboratories, Madison, WI, 2010.

LAGSDON, N.B.; FINGER, Z.; JESUS, J.M.H. Influência do ângulo entre o esforço aplicado e a direção das fibras da madeira sobre a resistência ao cisalhamento. Engenharia Civil, Universidade do Minho, Portugal, n. 37, p. $5-16,2010$.

LAGSDON, N.B.; FINGER, Z.; JESUS, J.M.H. Influência do ângulo entre a força e as fibras da madeira na resistência à tração. Advances in the forestry science, Cuiabá, v.01, n.3, p. 95 - 100, 2014.

LOBÃO, M.S.; DELLA LUCIA, R.M.; MOREIRA, M.S.S.; VITAL, B.R.; ALVARENGA, R.C.S.; GOUVÊA, A.F.G. Avaliação experimental de vigas com emendas de topo coladas com cobrejuntas de madeira de eucalipto. Revista árvore, Viçosa, v. 36, n. 2, p. 357 - 364, 2012.

MASCIA, N.T.; NICOLAS, E.A.; TODESCHINI, R. Comparison between Tsai-Wu failure criterion and Hankinson's formula for tension in wood. Wood Research, v.56, n.4, p. 499-510, 2011. 